\title{
RELASI LEMBAGA NEGARA DALAM PERSPEKTIF UNDANG UNDANG DASAR NEGARA REPUBLIK INDONESIA 1945
}

\author{
Abustan \\ Fakultas Hukum Universitas Islam Jakarta, Jakarta \\ Email : cakbus.community@gmail.com
}

\begin{abstract}
The basic principles of the state in order to be operational must be spelled out in relation to the pattern of power between state institutions, Implementation of the explanation of relations is done through the constitution, the attitude for need of Indonesian citizens to understand in full and complete about the various relationships between state institutions in the perspective of the UUD NRI 1945 Constitution of the Republic of Indonesia. The purpose of this study is to know how the background or history of the Constitution. to know and analyze how the relation of state institutions today, and how the practice of institutional arrangements in the current era of reform., after being conducted four times the amendment of the Constitution. This research method used normative juridical. The result of this research is the natural implementation of law enforcement power, for example, even though it is determined that the power to make law is owned by DPR, but in its implementation requires cooperation with the co legislator, that is the President and the DPD (for the design of certain laws), a provision of law which has obtained the approval of the DPR and the President and has been ratified and make the law can say no legal force binding the Constitutional Court (MK), if declared contradictory to the Constitution. This shows a very serious problem with regard to the relation of state institutions after the amendment (post-reform). so the conclusion is that if the arrangement of relation of state institution fails to do, it will result in the weakening of the state system which is based on the principles of democracy, state law and constitutionalism. The function of each power must adhere to the principle of trias politics.
\end{abstract}

Keywords: Relation, regulation, institution.

Abstrak
Prinsip-prinsip dasar yang ada di negara agar menjadi operasional, harus harus dijabarkan ke dalam
relasi pola kekuasaan antara lembaga negara. Implementasi penjabaran relasi itu di lakukan melalui
konstitusi. Bahkan, perlunya sikap warga negara Indonesia (WNI) memahami secara utuh dan
lengkap mengenai berbagai relasi antar lembaga negara dalam perspektif UUD NRI 1945. Tujuan
dari penelitian ini adalah untuk mengetahui bagaimana latar belakang atau sejarah perubahan UUD
NRI 1945, untuk mengetahui dan menganalisis bagaimana relasi lembaga negara saat ini, setelah
dilakukan empat kali perubahan UUD NRI 1945 serta untuk mengetahui dan menganalisis
bagaimana praktek penataan kelembagaan di era roformasi sekarang ini. Metode penelitian ini
mneggunakan yuridis normative dengan alat pengumpul data melalui studi kepustakaan dan untuk
menganalisnya menggunakan deskriptif analisis. Hasil penelitian ini adalah alam pelaksanaan
kekuasaan pembuatan undang-undang misalnya, walaupun ditentukan kekuasaan membuat undang-
undang duniliki oleh DPR, namun dalam pelaksanaannya membutuhkan kerja sama dengan
colegislator, yaitu Presiden dan DPD (untuk rancangan undang-undang tertentu), bahkan suatu
ketentuan undang-undang yang telah mendapatkan persetujuan bersama DPR dan Presiden serta
telah disahkan dan diundangkan pun dapat dinyatakan tidak mempunyai kekuatan hukum mengikat
oleh Mahkamah Konsitusi (MK) jika dinyatakan bertentangan dengan UUD 1945. Hal ini
menunjukkan persoalan yang sangat serius berkenaan dengan relasi lembaga negara setelah 
amandemen (pasca reformasi). Kesimpulan yaitu jika penataan relasi lembaga negara gagal dilakukan, maka akan berakibat pada makin melemahnya sistem ketatanegaraan yang di dasarkan pada prinsip-prinsip demokrasi, negara hukum, dan konstitusionalisme. Fungsi kekuasaan masingmasing harus berpegang pada prinsip trias politika.

Kata kunci : Relasi, penataan, kelembagaan.

\section{PENDAHULUAN}

Salah satu keberhasilan yang dicapai oleh bangsa Indonesia pada masa reformasi adalah perubahan konstitusional (constitutional reform) dalam bentuk Perubahan UUD NRI 1945 yang dilakukan dalam empat perubahan. Perubahan tersebut cukup besar baik dilihat dari sisi kuantitas maupun kualitasnya. Dari segi kuantitas saja sudah dapat disimpulkan bahwa sesungguhnya UUD NRI 1945 setelah mengalami empat kali amandemen mengalami perubahan secara signifikan, walaupun nama UUD Negara Republik Indonesia Tahun 1945 tetap dipertahankan.

Dilihat dari sisi kualitasnya, perubahan dapat dilihat dari persektif peniikiran atau pokok-pokok pikiran yang terkandung dalam rumusan pasal-pasal UUD NRI 1945 setelah mengalami empat kali perubahan itu benarbenar berbeda dari pokok pikiran yang terkandung dalam naskah asli ketika UUD NRI 1945 pertama kali disahkan pada tanggal 18 Agustus 1945. Bahkan, dalam Pasal II aturan tambahan perubahan keempat UUD NRI 1945 ditegaskan, "Dengan ditetapkannya perubahan Undang-Undang Dasar ini, Undang-Undang Dasar Negara Republik Indonesia Tahun 1945 terdiri atas pembukaan dan pasal-pasal". Dengan demikian, jelaslah bahwa sejak tanggal 10 Agustus 2002, status Penjelasan UUD NRI 1945 yang selama ini dijadikan lampiran tak terpisahkan dari naskah UUD NRI 1945, tidak lagi diakui sebagai bagian dari naskah UUD. Jikapun isi Penjelasan itu dibandingkan dengan isi UUD NRI 1945 setelah empat kali berubah, jelas satu sama lain sudah tidak lagi bersesuaian, karena pokok pikiran yang terkandung di dalam keempat naskah perubahan itu sama sekali berbeda dari apa yang tercantum dalam Penjelasan UUD NRI 1945 tersebut.

Atas dasar itulah, keberhasilan melakukan perubahan konstitusional, tahapan selanjutnya yang harus dilakukan adalah pelaksanaan UUD NRI 1945 yang telah diubah tersebut. Pelaksanaan UUD NRI 1945 meliputi berbagai aktivitas, mulai dari konsolidasi norma hukum hingga praktiknya, serta melibatkan segenap komponen bangsa, baik penyelenggara negara maupun warga negara. Hal ini terkait dengan fungsi konstitusi yang tidak hanya sekadar mengatur masalah politik dan kelembagaan negara.

UUD1945 merupakan satu kesatuan rangkaian perumusan hukum dasar Indonesia. Isinya mencakup dasar-dasar normatif yang berfungsi sebagai sarana pengendali (tool of social and political control) terhadap penyimpangan dan penyelewengan dalam dinamika perkembangan zaman dan sekaligus sarana pembaruan masyarakat (tool of social and political reform) serta sarana perekayasaan (tool of social and political engineering) ke arah citacita kolektif bangsa.

Keseluruhan kesepakatan yang menjadi materi konstitusi pada intinya menyangkut prinsip pengaturan dan pembatasan kekuasaan. Karena itu, menurut William G. Andrews, "Under constitutionalism, two types of limitations impinge on government. Power proscribe and procedures prescribed." Kekuasaan melarang dan prosedur ditentukan. Konstitusionalisme mengatur dua relasi yang saling berkaitan satu sama lain, yaitu: Pertama, relasi antara pemerintahan dengan warga negara; dan Kedua, relasi antara lembaga pemerintahan yang satu dengan lembaga pemerintahan yang lain. Karena itu, biasanya, isi konstitusi dimaksudkan untuk mengatur mengenai tiga hal penting, yaitu: (a) menentukan

1 William G. Andrews, 1968, Contstitutions and Constitutionalism, $3^{\text {rd }}$ edition, New Jersey: Van Nostrand Company, hlm. 13. 
pembatasan kekuasaan organ-organ negara, (b) mengatur relasi antara lembaga-lembaga negara yang satu dengan yang lain, dan (c) mengatur relasi kekuasaan antara lembaga-lembaga negara dengan warga negara.

Dengan demikian, salah satu materi penting dan selalu ada dalam konstitusi adalah pengaturan, tentang relasi lembaga negara. Hal ini dapat dimengerti karena kekuasaan negara pada akhirnya diterjemahkan ke dalam tugas dan wewenang lembaga negara. Tercapai tidaknya tujuan bernegara berujung pada bagaimana lembaga-lembaga negara tersebut melaksanakan tugas dan wewenang konstitusionalnya serta pilihan penyelenggaraan negara dalam bentuk relasi antar lembaga negara. Pengaturan lembaga negara dan relasi antar lembaga negara merefleksikan pilihan dasar-dasar kenegaraan yang dianut.

Di dalam UUD NRI 1945, dari 21 bab yang ada, terdapat 11 bab yang di dalamnya mengatur tentang lembaga negara. Namun, pengaturan tentang lembaga negara tersebut memiliki perbedaan substansi yang diatur. Ada lembaga negara yang diatur secara lengkap mulai dari cara pemilihan, tugas dan wewenangnya, begitupun relasinya dengan lembaga negara lain, hingga cara pemberhentian pejabatnya. Namun, ada pula lembaga negara yang keberadaannya ditentukan secara umum melaksanakan fungsi tertentu tanpa menentukan nama lembaga tersebut, seperti, komisi pemilihan umum dan bank sentral.

\section{RUMUSAN MASALAH}

Adapun permasalahn masalah yang diteliti antara lain adalah sebagai berikut : 1).Bagaimana Prinsip-Prinsip Penataan Lembaga Negara dikaitkan dengan latar belakang / sejarah perubahan UUD NRI 1945 ?; 2). Bagaimana relasi lembaga negara saat ini secara kelembagaan, setelah dilakukan empat kali perubahan UUD NRI 1945 ?; dan 3). Bagaimana praktek penataan kelembagaan di era roformasi sekarang ini dikaitkan dengan Warga Negara?

\section{METODE PENELITIAN}

Metode yang digunakan dalam penelitian ini adalah yuridis normative yaitu pengumupaln data melalui studi kepustakaan berupa bahan hokum primer mulai dari Unadng Undang Dasar Negara Republik Indonesia 1945 dan bahan hokum sekunder yaitu sumber-sumber yang berkaitan dengan penelitian ini yaitu buku, jurnal, teori-teori dari para ahli, sedangkan sifat penelitain ini adalah deskriptif analisis yaitu dengan cara mengumpulkan bahan yang sesuai dengan pengkajian ini kemudian dipelajari dan dituangkan dalam bentuk narasi serta dianalisis.

\section{PEMBAHASAN}

\section{Prinsip-Prinsip Penataan Lembaga Negara}

Dalam perspektif UUD NRI 1945 yang bersifat mendasar tentu mengakibatkan pada perubahan kelembagaan negara. Hal itu tidak saja karena adanya perubahan terhadap butirbutir ketentuan yang mengatur tentang kelembagaan negara, tetapi juga karena perubahan perspektif hukum dan ketatanegaraan. Beberapa prinsip-prinsip mendasar yang menentukan relasi antarlembaga negara di antaranya adalah:

\section{a. Supremasi Konstitusi}

Salah satu perubahan mendasar dalam UUD NRI 1945 adalah perubahan Pasal 1 ayat (2) yang berbunyi "Kedaulatan berada di tangan rakyat dan dilaksanakan menurut Undang-Undang Dasar." Ketentuan ini membawa implikasi bahwa kedaulatan rakyat tidak lagi dilakukan sepenuhnya oleh MPR, tetapi dilakukan menurut ketentuan Undang-Undang Dasar. MPR tidak lagi menjadi lembaga tertinggi negara di atas lembaga-lembaga tinggi negara.

Berdasarkan ketentuan Pasal 1 ayat (2) UUD NRI 1945 tersebut, UUD NRI 1945 menjadi dasar hukum tertinggi pelaksanaan kedaulatan rakyat. Hal itu berarti kedaulatan rakyat dilakukan oleh seluruh organ konstitusional dengan masingmasing fungsi dan kewenangannya berdasarkan UUD NRI 1945. Jika berdasarkan ketentuan Pasal 1 ayat (2) UUD NRI 1945 sebelum perubahan 
kedaulatan dilakukan sepenuhnya oleh MPR dan kemudian didistribusikan kepada lembaga-lembaga tinggi negara, maka berdasarkan hasil perubahan Pasal 1 ayat (2) UUD NRI 1945 kedaulatan tetap berada di tangan rakyat dan pelaksanaannya langsung didistribusikan secara fungsional (distributed functionally) kepada organorgan konstitusional.

Dengan demikian konsekuensi yuridisnya, setelah Perubahan UUD NRI 1945 tidak dikenal lagi konsepsi lembaga tertinggi dan lembaga tinggi negara. Lembaga-lembaga negara yang merupakan organ konstitusional kedudukannya tidak lag, seluruhnya hierarkis di bawah MPR, tetapi sejajar dan saling berrelasi berdasarkan kewenangan masing-masing berdasarkan UUD NRI 1945.

\section{b. Sistem Presidensial}

Fakta ketatangeraan kita menunjukkan, sebelum adanya Perubahan UUD NRI 1945, sistem pemerintahan yang dianut tidak sepenuhnya sistem presidensial. Jika dilihat relasi antara DPR sebagai parlemen dengan Presiden yang sejajar (neben), serta adanya masa jabatan Presiden yang ditentukan (fix term) memang menunjukkan ciri sistem presidensial. Namun, jika dilihat dari keberadaan MPR yang memilih, memberikan mandat, dan dapat memberhentikan Presiden, maka sistem tersebut memiliki ciri-ciri sistem parlementer. Presiden adalah mandataris MPR dan sebagai konsekuensinya Presiden bertanggung jawab kepada MPR dan MPR dapat memberhentikan Presiden?2.

Salah satu kesepakatan dalam Sidang Tahunan MPR Tahun 1999 terkait Perubahan UUD NRI 1945 adalah "sepakat untuk mempertahankan sistem presidensial (dalam pengertian sekaligus

2 Abustan, Penataan Lembaga Negara Refleksi Penguatan Sistem Presidensial, Al Adl Jurnal Hukum, Nolume 9 Nomor 2, 2017 Banjarmasin: Fakultas Hukum Uniska, Hlm. 195-214. menyempumakan agar betul-betul memenuhi ciri-ciri umum sistem presidensial). " Penyempurnaan dilakukan dengan perubahan-perubahan ketentuan UUD NRI 1945 terkait sistem kelembagaan. Perubahan mendasar pertama adalah perubahan kedudukan MPR yang mengakibatkan kedudukan MPR tidak lagi merupakan lembaga tertinggi negara, sebagaimana telah dibahas sebelumnya. Perubahan selanjutnya untuk menyempurnakan sistem presidensial adalah menyeimbangkan legitimasi dan kedudukan antara lembaga ek,ekutif dan legislatif, dalam hal ini terutama antara DPR dan Presiden. Hal ini dilakukan dengan pengaturan mekanisme pemilihan Presiden dan Wakil Presiden yang dilakukan secara langsung oleh rakyat dan mekanisme pemberhentian dalam masa jabatan sebagaimana diatur dalam Pasal 6, 6A, 7, 7A, dan 8 UUD NRI 1945. Karena Presiden dan Wakil Presiden dipilih secara langsung oleh rakyat, maka memiliki legitimasi kuat dan tidak dapat dengan mudah diberhentikan kecuali karena melakukan tindakan pelanggaran hukum.

Proses usulan pemberhentian Presiden dan atau Wakil Presiden tidak lagi sepenuhnya diserahkan kepada mekanisme politik, tetapi dengan mengingat dasar usulan pemberhentiannya adalah masalah pelanggaran hukum, maka proses hukum melalui Mahkamah Konstitusi harus dilalui. Di sisi yang lain, kekuasaan Presiden membuat Undang-Undang sebagaimana diatur dalam Pasal 5 ayat (1) UUD NRI 1945 sebelum Perubahan, diganti dengan hak mengusulkan rancangan undang-undang dan diserahkan kepada DPR sebagaimana diatur dalam Pasal 20 ayat (1) UUD NRI 1945. Selain itu juga ditegaskan Presiden tidak dapat membubarkan DPR sebagaimana diatur dalam Pasal 7C UUD NRI 1945.

\section{c. Pemisahan Kekuasaan dan Check and Balances}

Sebelum perubahan UUD NRI 1945 , 
sistem kelembagaan yang dianut bukan pemisahan kekuasaan (separation of power) tetapi sering disebut dengan istilah pembagian kekuasaan (distribution of power). Presiden tidak hanya memegang kekuasaan pemerintahan tertinggi (eksekutio tetapi juga memegang kekuasaan membentuk undang-undang atau kekuasaan legislatif bersama-sama dengan DPR sebagai co-legislator-nya. Sedangkan, masalah kekuasaan kehakiman (yudikatif dalam UUD NRI 1945 sebelum perubahan dilakukan oleh sebuah Mahkamah Agung dan lain-lain badan kehakiman menurut undangundang, sesuai dengan prisip trias politika ${ }^{3}$.

Dengan adanya perubahan kekuasaan pembentukan undang-undang yang semula dimiliki oleh Presiden menjadi dimiliki oleh DPR berdasarkan hasil Perubahan UUD NRI 1945, terutama Pasal 5 ayat (1) dan Pasal20 ayat (1), maka yang disebut sebagai lembaga legislatif (utama) adalah DPR, sedangkan lembaga eksekutif adalah Presiden. Walaupun dalam proses pembuatan suatu undang-undang dibutuhkan persetujuan Presiden, namun fungsi Presiden dalam hal ini adalah sebagai co-legislator sama seperti DPD untuk materi undang-undang tertentu, bukan sebagai legislator utama. Sedangkan kekuasaan kehakiman (yudikatif dilakukan oleh Mahkamah Agung (dan badan-badan peradilan di bawahnya) dan Mahkamah Konstitusi berdasarkan Pasal 24 ayat (2) UUD NRI 1945.

Relasi antara kekuasaan eksekutif yang dilakukan oleh Presiden, kekuasaan legislatif oleh DPR (dan dalam hal tertentu DPD sebagai co-legislator), dan kekuasaan yudikatif yang dilakukan oleh NIA dan MK merupakan perwujudan sistem checks and balances. Sistem checks and balances

3 Gios Adhyaksa Dan Suwari Akhmaddhian, Pengelolaan Dana Otonomi Berdasarkan Undang Undang Daerah Istimewa Provinsi Aceh Dan Undang Undang Otonomi Khusus Provinsi Papua, UNIFIKASI: Jurnal Ilmu Hukum, Volume 2 Nomor 2, 2015, Fakultas Hukum Universitas Kuningan, hlm. 78-102. dimaksudkan untuk mengimbangi pembangian kekuasaan yang dilakukan agar tidak terjadi penyalahgunaan kekuasaan oleh lembaga pemegang kekuasaan tertentu atau terjadi kebuntuan dalam relasi antarlembaga. Oleh karena itu, dalam pelaksanaan suatu kekuasaan selalu ada peran tertentu dari lembaga lain.

Dalam pelaksanaan kekuasaan pembuatan undang-undang misalnya, walaupun ditentukan kekuasaan membuat undang-undang dimiliki oleh DPR, namun dalam pelaksanaannya membutuhkan kerja sama dengan co-legislator, yaitu Presiden dan DPD (untuk rancangan undang-undang tertentu). Bahkan suatu ketentuan undangundang yang telah mendapatkan persetujuan bersama DPR dan Presiden serta telah disahkan dan diundangkan pun dapat dinyatakan tidak mempunyai kekuatan hukum mengikat oleh MK jika dinyatakan bertentangan dengan UUD NRI 1945.

Di sisi lain, Presiden dalam menjalankan kekuasaan pemerintahannya mendapatkan pengawasan dari DPR. Pengawasan tidak hanya dilakukan setelah suatu kegiatan dilaksanakan, tetapi juga pada saat dibuat perencanaan pembangunan dan alokasi anggarannya. Bahkan kedudukan DPR dalam hal ini cukup kuat karena memiliki fungsi anggaran secara khusus selain fungsi legislasi dan fungsi pengawasan sebagaimana diatur pada Pasal 20A UUD NRI 1945. Namun demikian kekuasaan DPR juga terbatas, DPR tidak dapat menjatuhkan Presiden dan atau Wakil Presiden kecuali karena alasan pelanggaran hukum. Usulan DPR tersebut harus melalui forum hukum di MK sebelum dapat diajukan ke MPR.

\section{Relasi Kelembagaan dan Dilema dalam Realitas \\ Salah satu aspek penting berkenaan} dengan kelembagaan negara adalah aspek relasi penetaan relasi ini, akan ditentukan oleh kualifikasi sebagai badan ketatanegaraan atau bukan badan ketatanegaraan. Dalam kaitan ini, 
Bagir Manan menjelaskan:

"Dari tinjauan hukum, relasi kelembagaan negara dapat bersifat ketatanegaraan (staatsrechtelijk) atau tidak bersifat ketatanegaraan misalnya relasi yang bersifat administratif (administratiefrechtelijk). Tetapi tidak sebaliknya. Badan-badan yang bukan lembaga kenegaraan tidak dapat melakukan relasi yang bersifat ketatanegaraan, karena relasi itu tidak dilakukan untuk dan atas nama negara. Kalaupun dalam keadaan tertentu dipandang melakukan tugas yang bersifat ketatanegaraan, hal itu semata karena suatu "pelimpahan" dari pemegang kekuasaan asli (original power) ketatanegaraan. Tugas dan wewenang ketatanegaraan badan semacam ini bersifat derivatif belaka (tidak original). Misalnya kejaksaan yang bertindak untuk dan atas nama negara, semata-mata karena pelimpahan dari penyelenggara negara dibidang pemerintahan (eksekutif)". ${ }^{4}$

Tidak hanya itu, tapi Bagir Manan menjelaskan bahwa dalam realitas dijumpai beraneka ragam relasi antar kelembagaan negara, antara lain: ${ }^{5}$

a. Relasi kerjasama atau relasi kolegial sebagaimana diperlihatkan melalui relasi kerjasama antara DPR dan Presiden dalam hal pembentukan undang-undang.

b. Relasi pertanggungjawaban dalam sistem pemerintahan parlementer dimana cabang kekuasaan eksekutif bertanggung jawab kepada cabang kekuasaan legislatif.

c. Relasi checks and balances.

Sebagaimana telah disebutkan di atas, berbagai kerancuan pengertian menimbulkan persoalan-persoalan yang cukup mengganggu relasi antar lembaga. DPR muncul sebagai penyelenggara negara yang sangat dominan

4 Bagir Manan, 2006, Hubungan Ketatanegaraan Mahkamah Agung (dan Mahkamah Konstitusi) Dengan Komisi Yudisial (Suatu Pertanyaan), Makalah, 2006, hlm.2

5 Bagir Manan, 2016, Lembaga-lembaga Negara Didalam dan Diluar 1945, Makalah, 2016, hlm.11 melalui berbagai hak yang dimilikinya. Atas dasar alasan melaksanakan fungsi anggaran (hak budget), DPR ikut menentukan besaran anggaran secara detail yang mengakibatkan terbukanya kesempatan melakukan korupsi.

Fungsi lain yang acapkali digunakan untuk "mengganggu" cabang kekuasaan lain, adalah fungsi pengawasan. Setelah Reformasi, bahkan fungsi pengawasan lebih dikedepankan dibandingkan dua fungsi lainnya. Prestasi di bidang fungsi legislatif tidak terlalu menggembirakan. DPR tampak lebih "mengutamakan" undang-undang di bidang politik dan pemerintahan. Hal ini terlihat nyata dengan adanya semacam "ritual" lima tahunan untuk mengubah UU Pemilihan Umum ataupun UU Partai Politik.

Sebagaimana telah disebutkan di atas, saat ini DPR sedang menggunakan hak angket dalam rangka pengawasan. Dalam sejarah ketatanegaraan Indonesia, hak angket pernah digunakan dalam rangka memperbaharui suatu undang-undang warisan Belanda ketika Alm. Margono Djojohadikusumo memimpin Panitia Angket saat menjadi anggota DPRS tahun 1950an. ${ }^{6}$ Dalam UU MD3, hak angket diatur dalam Pasal 79 ayat (1) dan ayat (3) serta Pasal-pasal 199-209 (tata cara melaksanakan angket) dan Peraturan Tata Tertib DPR. Pasal 79 ayat (3) UU MD3 menyatakan:

"Hak DPR untuk melakukan penyelidikan terhadap pelaksanaan suatu undangundang dan/atau kebijakan Pemerintah yang berkaitan dengan hal penting, strategis, dan berdampak luas pada kehidupan bermasyarakat, berbangsa, dan bernegara yang diduga bertentangan dengan peraturan perundang-undangan".

Atas dasar ketentuan tersebut, Bagir Manan berpendapat suatu persoalan layak menjadi obyek mengadakan angket, haruslah dikembalikan pada dasar penggunaan hak angket yaitu: ${ }^{7}$

(1) Apakah obyek-obyek tersebut merupakan

\footnotetext{
${ }^{6}$ Bagir Manan, 2017, Hak Angket Sebagai Kekuasaan Pengawasan DPR, Makalah, hlm.5

${ }^{7}$ Ibid., hlm.12
} 
hal penting, strategis dan berdampak luas terhadap kehidupan bermasyarakat, berbangsa dan bernegara?

(2) Apakah ada bukti-bukti awal yang cukup, pelaksanaan undang-undang dan kebijakan hal-hal yang menjadi obyek angket melanggar undangundang?

Kewenangan lain yang juga makin memperkuat dominasi serta pengaruh adalah kewenangan ikut serta menentukan pejabatpejabat publik melalui mekanisme "fit and proper test". Pengisian Hakim Konstitusi, misalnya, seringkali diwarnai pengaruh politik untuk menentukan calon yang dikehendaki atas dasar preferensi politik. Hal serupa terjadi dalam pengisian Hakim Agung. ${ }^{8}$ Oleh sebab itu, dalam praktik terjadi apa yang disebut dengan politicking, yaitu suatu proses yang memasukkan tata kerja yang bersifat politik untuk suatu kedudukan atau fungsi yang bukan politik. ${ }^{9}$

Keseluruhan persoalan di atas terjadi akibat sistem politik yang tidak sehat yang mengakibatkan berkurangnya kualitas para anggota DPR. Para anggota seakan-akan mengalami "political shock" karena memiliki kewenangan yang sangat besar, namun tidak tahu bagaimana mengelola kewenangan tersebut untuk menjalankan fungsi-fungsi yang berwujud dalam berbagai hak atas dasar prinsip-prinsip konstitusional serta negara hukum yang demokratis, UUD NRI 1945 merupakan rule of the game dalam menjalankan kehidupan berbangsa dan bernegara di Indonesia ${ }^{10}$.

\section{Relasi Negara dan Warga Negara}

Dalam konteks negara dan warga negara, relasi beranjak dari makna warga negara yang

8 Lebih lanjut lihat Susi Dwi Harijanti, 2016, 'Pengisian Jabatan Hakim: Kebutuhan Reformasi dan Pengekangan Diri', Jurnal Hukum lus Quia Iustum, No. 4, Vol 21, 2016, hlm 531-558.

9 Pengertian politicking dalam tulisan ini menggunakan definisi yang disampaikan oleh Bagir Manan, 'Hakim Tinggi Daming Sunusi Dalam Kawah- Paiiticking', Makalah, 2013, hlm 1.

10 Erga Yuhandra, Kewenangan BPD (Badan Permusyawaratan Desa) Dalam Menjalankan Fungsi Legislasi, UNIFIKASI: Jurnal Ilmu Hukum, Volume 3 Nomor 2, 2016, hlm. 61-76. menunjuk pada "keanggotaan" seseorang dalam negara tersebut yang menimbulkan hak dan kewajiban yang bersifat timbal balik. Apa yang menjadi hak bagi seseorang merupakan kewajiban bagi negara untuk memenuhinya, sebaliknya negara berhak untuk meminta seseorang melaksanakan kewajibannya.

'Are You Being Served: State, Citizen, Governance' merupakan salah satu buku menarik yang menggambarkan relasi negara dan warga negara. Buku ini diterbitkan pada tahun 2001 dengan editor Glyn Davis dan Patrick Wellar. ${ }^{11}$ Para kontributor artikel dalam buku ini menjelaskan bahwa perubahan perspektif governance yang terjadi pada akhir 1990-an mengakibatkan relasi antara negara atau pemerintah dengan warga negara mengalami perubahan. Harapan masyarakat dalam menerima pelayanan yang diselenggarakan oleh negara atau pemerintah bergeser. Semula sebagai penerima yang bersifat pasif menjadi penerima yang aktif dalam arti dapat melakukan "gugatan" jika pelayanan tidak memadai. Perubahan lain berkenaan dengan penyelenggara pelayanan publik. Sebelum tahun 1990an, pelayanan publik dilakukan oleh institusi atau lembaga pemerintah. Dengan alasan efisiensi, negara atau pemerintah melakukan privatisasi pelayanan publik.

Ditinjau dari aspek relasi antara rakyat dengan negara, salah satu fungsi mendasar negara modern adalah memberikan pelayanan (the service state). Pelayanan merupakan salah satu bentuk pekerjaan konkrit pemerintah terhadap rakyat. ${ }^{12}$ Bahkan secara eksplisit Bagir Manan menyatakan 'pelayanan itu sendiri dipertalikan dengan kesejahteraan umum, bukan sekedar sebutan the service state atau verzorgingsstaat'.13 Pelayanan dapat terselenggara dengan baik apabila pemerintah

${ }^{11}$ Glyn Davis dan Patrick Wellar (eds), 2001, Are You Being Served: State Citizens, Governance, Sydney, Allen and Unwin, hlm 12-30.

12 Bagir Manan, 2009, Tugas Sosial Pemerintahan Daerah, Makalah, 2009, hlm 3.

${ }^{13}$ Bagir Manan, 2012, Pembangunan Hukum di Bidang Pelayanan, Makalah disampaikan pada Dialog Perencanaan Hukum Nasional yang diselenggarakan oleh Badan Pembinaan Hukum Nasional, Denpasar, 27 September 2012, hlm 10. 
mengetahui secara pasti kebutuhan rakyat yang dilayaninya. Selain itu, rakyat juga menyadari hak-hak yang dimilikinya sehingga apabila merasa tidak puas atas pelayanan yang diterima mereka dapat "menuntut" pemerintah. Dalam suatu negara yang berdasarkan prinsip negara hukum yang demokratis, bahkan setiap orang dapat "memperkarakan" negara atau pemerintah. Pengertian "memperkarakan" tidak semata-mata berrelasi dengan pengadilan, melainkan termasuk pula melalui 'mekanisme non-yudisial, misalnya melalui penyempaian keberatan atau keluhan kepada lembaga-lembaga yang memiliki kewenangan di bidang tersebut, misalnya Ombudsman.

Relasi negara dengan para warga negaranya berwujud dalam bentuk hak-hak asasi atau hak-hak konstitusional warga negara yang dijamin dalam UUD NRI 1945 serta peraturan perundang-undangan lainnya. Sebagaimana telah disebutkan dalam bagian terdahulu, UUD NRI 1945 memuat jaminan hak asasi yang lebih lengkap yang meliputi hak-hak sipil, politik, ekonomi, sosial serta budaya atau yang dkenal pula sebagai hak-hak substantif. Hak konstitusi ini bukan saja terdapat dalam $B a b X$ dan $X A$, melainkan juga dalam Bab Pemerintahan Daerah yang menjamin hak-hak tradisional masyarakat hukum adat. Meskipun tidak djamin secara eksplisit dalam UUD NRI 1945, hak-hak prosedural dijamin sebagai "statutory rights" dalam berbagai undang-undang, misalnya UU Pelayanan Publik dan UU Ombudsman Republik Indonesia.

Konstitusi adalah "the supreme law of the land". Memasukkan hakhak asasi sebagai ketentuan konstitusi atau undang-undang dasar, tidak saja menegaskan hak asasi sebagai fundamental rights, melainkan sekaligus sebagai "the supreme constitutional rights". ${ }^{14} \mathrm{Hal}$ ini mengakibatkan negara atau pemerintah mempunyai tiga kewajiban dasar yang harus dipenuhi, yaitu kewajiban melakukan penghormatan, kewajiban melakukan

14 Bagir Manan dan Susi Dwi Harijanti, 2016, Konstitusi dan Hak Asasi Manusia, PJIH, Vol. 3, No. 3, 2016, hlm 465. perlindungan, serta kewajiban melakukan pemenuhan.

Kewajiban melakukan penghormatan membawa negara atau pemerintah tidak dapat secara sewenang-wenang mencampuri baik secara langsung maupun tidak langsung. Misalnya, berkenaan dengan hak atas pendidikan. Kewajiban menghormati menyebabkan negara atau pemerintah dilarang melakukan tindakan yang menghalang-halangi pelaksanaan hak atas pendidikan. Kewajiban melakukan proteksi berarti negara atau pemerintah harus mengambil langkah-langkah atau tindakan-tindakan yang mencegah pihak ketiga melakukan pelanggaran, seperti membiarkan pihak swasta menerapkan ketentuan uang sekolah yang sangat tinggi. Kewajiban melakukan pemenuhan mengharuskan negara atau pemerintah melakukan tindakantindakan tertentu agar hak mendapatkan sekolah gratis untuk tingkat pendidikan dasar dapat dinikmati oleh semua orang, yaitu warga negara Indonesia.

\section{SIMPULAN}

Berdasarkan uraian di atas maka penulis dapat menyimpulkan hal - hal sebagai berikut : a). Perubahan UUD NRI 1945 telah mengubah sistem ketatanegaraan Indonesia secara fundamental. Sebelum perubahan UUD 1945, sistem kelembagaan yang dianut bukan pemisahan kekuasaan (separation of power) tetapi wring disebut dengan istilah pembagian kekuasaan (distribution of power). Hal ini dilatar belakangi agar tidak terjadi penyalagunaan kekuasaan oleh lembaga tertentu; b). Saat ini, Presiden tidak hanya memegang kekuasaan pemerintahan tertinggi (eksekutio tetapi juga memegang kekuasaan membentuk undang-undang atau kekuasaan legilaatof bersama-sama dengan DPR sebagai co-legislator-nya; dan c). Relasi antara kekuasaan eksekutif yang dilakukan oleh Presiden, kekuasaan legislatif oleh DPR - DPD, dan kekuasaan yudikatif yang dilakukan oleh MA dan MK merupakan perwujudan sistem checks and balances. Sistem checks and balances di era reformasi sekarang ini 


\section{SARAN}

Berdasarkan uraian di atas maka dapat disimpulkan hal - hal sebagai berikut: a). Agar tidak terus menimbulkan polemik terhadap kekuasaan pembentukan undang - undang yang semula dimiliki oleh presiden menjadi dimiliki oleh DPR berdasarkan hasil perubahan UUD NRI 1945, maka diperlukan penegasan tentang lembaga legislatif (utama) DPR, dan lembaga eksekutif adalah presiden; b). Agar tugas dan fungsi DPD bisa dimaksimalkan maka haruslah diposisikan sebagai legislator utama, bukan sebagai co - legislator; dan c). Demi adanya keseimbangan dalam pelaksanaan suatu kekuasaan, sehingga menjadi penting dilakukan penataan terhadap relasi lembaga negara dalam perspektif UUD NRI 1945.

\section{DAFTAR PUSTAKA}

Abustan. Penataan Lembaga Negara Refleksi Penguatan Sistem Presidensial. Al Adl Jurnal Hukum, Nolume 9 Nomor 2. 2017. Fakultas Hukum Uniska.

Adhyaksa, Gios Dan Suwari Akhmaddhian. Pengelolaan Dana Otonomi Berdasarkan Undang Undang Daerah Istimewa Provinsi Aceh Dan Undang Undang Otonomi Khusus Provinsi Papua. UNIFIKASI: Jurnal IImu Hukum. Volume 2 Nomor 2. 2015. Kuningan : Fakultas Hukum Universitas Kuningan. DOI: $h$ ttps://doi.org/10.25134/unifikasi.v2i2.413

Manan, Bagir, 2017, Hak Angket Sebagai Kekuasaan Pengawasan DPR, Makalah.

Manan, Bagir dan Susi Dwi Harijanti, 2016, Konstitusi dan Hak Asasi Manusia, PJIH, Vol. 3, No. 3, 2016

Manan, Bagir, 2016, Lembaga-lembaga Negara Didalam dan Diluar 1945, Makalah, 2016

Manan, Bagir, 2013. Hakim Tinggi Daming Sunusi Dalam Kawah- Paiiticking, Makalah.

Manan, Bagir, 2012. Pembangunan Hukum di Bidang Pelayanan, Makalah disampaikan pada Dialog Perencanaan Hukum Nasional yang diselenggarakan oleh
Badan Pembinaan Hukum Nasional, Denpasar, 27 September 2012.

Manan, Bagir, 2009. Tugas Sosial Pemerintahan Daerah, Makalah, 2009. Fiat Justitia Jurnal Ilmu Hukum Volume 7 no. 3 Sep Des 2013, ISSN 1978-5186

Manan, Bagir, 2006, Hubungan Ketatanegaraan Mahkamah Agung (dan Mahkamah Konstitusi) Dengan Komisi Yudisial (Suatu Pertanyaan), Makalah, 2006.

Glyn Davis dan Patrick Wellar (eds), 2001, Are You Being Served: State Citizens, Governance, Sydney, Allen and Unwin.

Susi Dwi Harijanti, 2016. Pengisian Jabatan Hakim Kebutuhan Reformasi dan Pengekangan Diri Jurnal Hukum lus Quia Iustum, No. 4, Vol 21, 2016.

William G. Andrews, 1968, Contstitutions and Constitutionalism, 3rd edition, (New Jersey: Van Nostrand Company,)

Yuhandra, Erga. Kewenangan BPD (Badan Permusyawaratan Desa) Dalam Menjalankan Fungsi Legislasi (Sebuah Telaah Sosiologis Proses Pembentukan Perdes Di Desa Karamatwangi Kec. Garawangi Kab. Kuningan). UNIFIKASI: Jurnal Ilmu Hukum. Volume 3 Nomor 2. 2016. Fakultas Hukum Universitas Kuningan. DOI: $\underline{h t t p s: / / d o i . o r g / 10.25134 / u n i f i k a s i . v 4 i 1.477 ~}$ 